\title{
The action of ovarian hormones in cardiovascular disease
}

\author{
RODOLFO A MEDINA ${ }^{1}$, EVELYN ARANDA², CESAR VERDUGO², SUMIE KATO $^{2}$ and \\ GARETH I OWEN ${ }^{2}$
}

${ }^{1}$. Laboratorio de Biología Celular y Molecular, MIFAB, Universidad Nacional Andrés Bello, República 217, Piso 4, Santiago, Chile

2. Departamento de Endocrinología, Facultad de Ciencias Biológicas, Pontificia Universidad Católica de Chile, Alameda 340, Santiago, Chile

\begin{abstract}
The incidence of cardiovascular disease (CAD) differs between men and women, in part because of differences in risk factors and hormones. This sexual dimorphism means a lower incidence in atherosclerotic diseases in premenopausal women, which subsequently rises in postmenopausal women to eventually equal that of men. These observations point towards estrogen and progesterone playing a lifetime protective role against CAD in women. As exogenous estrogen and estrogen plus progesterone preparations produce significant reductions in low-density lipoprotein (LDL) cholesterol levels and significant increases in high-density lipoprotein (HDL) cholesterol, this should in theory lower the risk of CAD. However, results from oral contraceptive (OC) use and combined estrogen and progesterone hormone replacement therapy (HRT) have suggested that hormone replacement regimes do not provide cardiovascular protection. In fact, depending on the preparation and the presence or absence of genetic risk factors, an increased risk of cardiovascular diseases such as venous thrombosis, myocardial infarction (MI) and stroke have been observed. Interestingly, in the majority of studies the increase in risk was highest in the first year, after which an increase in risk was not observed, and in some studies a lower risk of CAD was evident after four or five years of exogenous hormone administration. While the debate continues about the merits of HRT, and several good reviews exist on the statistics of CAD in relation to exogenous hormones, we have decided to review the literature to piece together the physiological actions of estrogen and progesterone preparations on the individual mechanistic components leading to CAD; namely, the altered endothelium and the haemostatic balance between coagulation and fibrinolysis. We present possible mechanisms for how HRT and OCs protect against MI in the absence of cardiovascular risk factors but increase the incidence of $\mathrm{MI}$ in their presence. We also speculate on the roles played by hormones on the short- and long-term risks of cardiovascular disease.
\end{abstract}

Key terms: hormone replacement therapy (HRT), oral contraceptives, atherosclerosis cardiovascular disease, estrogen, progestins, venous thrombosis, myocardial infarction.

\section{INTRODUCTION}

Cardiovascular disease (CAD) is a general description incorporating several pathologies including coronary heart disease, stroke and venous thrombosis. CAD is the main cause of morbidity and mortality in Western countries (Murray \& Lopez, 1997). Differences in the incidence of hypertensive heart disease and coronary heart disease, atherosclerosis and cardiac remodeling after myocardial infarction (MI) between males and females are well established (Mendelsohn \& Karas, 1999; Stevensen, 2000). Estrogen improves welldefined risk factors, such as lipid profiles; it also has direct effects on the myocardium, endothelium, and vascular smooth muscle (VSM). Estrogens enhance flow of cholesterol from the diet through chylomicrons and chylomicron remnants to the liver, through very low-density lipoprotein (VLDL) and low-density lipoprotein (LDL) to cells, and through reverse cholesterol transport from cells via high-density lipoprotein (HDL) to the liver to be finally eliminated in the bile and intestine (Knopp, 1997). Estrogen increases levels of VLDL and subsequently the levels of triglycerides, decreases LDL levels due to the up-regulation of LDL receptors, and increases HDL due to increased secretion 
of apoA-I and reduced removal of HDL due to a reduction in hepatic lipase activity (Knopp, 1997; Espeland et al., 1998; Zhu et al., 1999; Mendelsohn \& Karas, 1999; Table I).

Estrogen is widely regarded as having beneficial effects on the three layers of the arterial wall; the intima (endothelium), the media, and the adventitia. These beneficial effects include reduction in plasma fibrinogen, plasminogen activator inhibitor (PAI-1) activity, reduced LDL oxidation in plasma, enhanced glucose metabolism, and enhanced insulin resistance (Knopp, 1997; Espeland et al., 1998; Mendelsohn \& Karas, 1999; Cushman et al., 1999; Sack et al., 1994; Table I). In the arterial endothelium, estrogen increases nitric oxide (NO) synthase activity and NO production (Hishikawa et al., 1995; Caulin-Glaser et al., 1997; Table I). NO is beneficial to arterial vasomotion in women who have angina pectoris due to vasospasm (Guetta and Cannon, 1996). In the intima and media of the arterial wall, estrogen reduces calcification and secretion of inflammatory cytokines, such as fibroblast growth factor (FGF), inter-cellular adhesion molecule (ICAM-1), vascular cell adhesion molecule (VCAM-1), endothelial- and plateletselectin (E- and $\mathrm{P}$-selectin), nuclear factor kappa $\mathrm{B}(\mathrm{NF} \kappa \mathrm{B})$ and consequently reduces the atherosclerosis which is associated with release of these cytokines in animal models (Knopp, 1997; Guetta and Cannon, 1996; Adams et al., 1990; Haarbo et al., 1991; Table I).

Conflicting results have been reported on the effects of progestins on atherosclerosis. Several studies demonstrate no effect in both primate and cholesterol-fed rabbit models (Adams et al., 1990; Haarbo et al., 1991). However, other studies have shown that natural progesterone and synthetic progestins oppose the beneficial effects of estrogen (Hanke et al., 1996; Adams et al., 1997). Progestins have been reported to oppose the estrogen-induced increase in plasma NO metabolites (Imthurn et al., 1997) which indicates that progestins inhibit NO production in endothelial cells and is further evidence of the proatherogenic effects of progestins in the presence of estrogen. Progestins appear to reduce the stimulatory effect of estrogens on lipoprotein transport in the bloodstream. For example, VLDL secretion is reduced; remnant removal is impaired, LDL receptors are down-regulated, increasing LDL-cholesterol levels; and HDL levels are reduced in response to increased hepatic lipase activity. Progestins also increase glucose, insulin and fibrinogen plasma levels (Knopp, 1997).

The estrogen receptor (ER) is classically a ligand-dependent nuclear transcription factor. However, recent evidence indicates that non-nuclear liganded ER can also regulate the activity of intracellular second messengers and membrane-associated receptors and signaling complexes (Ho \& Liao, 2002). In the cardiovascular system, these non-nuclear signaling pathways mediate rapid vasodilatation (White et al., 1995), inhibition of the response to vessel injury (White et al., 1997; Sullivan et al., 1995), reduction in myocardial injury after infarction (Node et al., 1997), and attenuation of cardiac hypertrophy (Douglas et al., 1998). The importance of estrogen in the cardiovascular system has been elucidated from ER knockout and mutation studies. In a single case study, a young man presented with homozygous disruption of the ER $\alpha$ gene, which resulted in the expression of a truncated receptor lacking both DNA and hormone-binding domains. This patient developed premature CAD and impaired brachial endotheliumdependent vasodilatation providing further evidence for a developmental and protective role for estrogen in the heart and protection from CAD (Sudhir et al., 1997a; Sudhir et al., 1997b). Studies in ovariectomized mice show that $17 ß$-estradiol inhibits intimal and medial vascular smooth muscle proliferation (Sullivan et al., 1995), implying a protective role for estrogen on both endothelial cells (EC) and vascular smooth muscle cells (VSMC). In ER knockout mice, 17ß-estradiol also inhibits medial thickening and VSMC proliferation in carotid injury studies (Iafrati et al., 1997). This suggests that the vascular protection produced by estrogen may be mediated in an ER $\alpha$-independent manner. Furthermore, 
when hearts from these mice are subjected to ischemia-reperfusion they present a greater degree of global ischemia and higher incidence of arrhythmias (Zhai et al., 2000). Studies which show that ovariectomized $\mathrm{ER} \alpha \mathrm{KO}$ mice exposed to cerebral ischemia have strokes which affect a greater area of the brain also demonstrate that $\operatorname{ER} \alpha$ mediates the neuroprotective effects of estrogen (Dubal et al., 2001). Evidence is also mounting that ER $\beta$ also has a role to play in the cardiovascular system. ERß expression is induced in VSMC after vascular injury (Linder et al., 1998), and ER $\beta K O$ mice are hypertensive and have VSMC ion channel dysfunction (Zhu et al., 2002).

OVARIAN HORMONES AND CARDIOVASCULAR DISEASE

\section{Venous disease}

Although sexual dimorphism converts to a lower incidence in arterial diseases in premenopausal women, exogenous hormones in the form of OCs and postmenopausal HRT have been associated with increased risk of venous thrombosis, MI and stroke. The presence of hormone preparations appears to add to the increased risk of venous thrombosis caused by genetic factors such as personal or family history, Factor V Leiden, deficiencies of protein C, protein $\mathrm{S}$, or antithrombin III and hyperhomocysteinemia. Emerging studies show that in vitro fertilization treatment and ovulation induction are also risk factors for venous thrombosis (Bloemenkamp et al., 2003). The risk for venous thrombosis is highest during the first year of OC use. Furthermore, OC users with inherited clotting defects develop venous thrombosis, not only more often, but also sooner, than do those without inherited clotting defects (Bloemenkamp et al., 2000). The nature of the exogenous hormone regime is also a risk factor (WHO, 1995). While the concentrations of estrogen have been declining since the first OC usage in the late 1950s, from values as high as $100 \mathrm{ug}$ mestranol to $15 \mathrm{ug}$ ethinyl estradiol, the progestin dosage has remained relatively constant. The World Heath Organization (WHO) concluded that although current users of estrogen and progesterone combined contraceptives have a low absolute risk of venous thromboembolism, their risk is still three to six times greater than that of nonusers, with the risk probably being highest during the first year of use (WHO, 1997). Although conflicting reports exist, the increase in venous thrombosis risk remains constant despite changes in the nature and dosage of estrogen. The progestin component, essential to suppress ovulation, has changed only in composition from first generation to third generation. As with estrogenic compounds, each progestin has been associated with an increased risk of CAD. This risk has been demonstrated to be greater for the newer third-generation than from secondgeneration progestins (Farmer \& Lawrenson, 1998).

The picture for CAD is no brighter in women taking HRT preparations. Unopposed estrogen treatment, while delivering beneficial relief from postmenopausal symptoms, also results in endometrial disorders such as endometriosis and cancer (Smith et al., 1975; Berger \& Fowler, 1997). Estrogen replacement therapy is still given to women who do not have a uterus, and medroxyprogesterone acetate (MPA) is added to the majority of current HRT preparations to counteract the endometrial abnormalities which arise from unopposed estrogen administration. In a trial of oral conjugated equine estrogen plus MPA, no overall reduction in CAD events was observed in postmenopausal women with established coronary disease. However, the treatment did lead to an increase in the rate of thromboembolic events and gallbladder disease (Hulley et al., 1998). As with OC, the intriguing observation was made that the risk of thrombotic events was higher in the first year of use, and there was a suggestion that the risk decreased to below control (placebo) levels after four to five years of treatment (reviewed in Rosendaal et al., 2002). This emerging pattern for exogenous hormone preparations indicates 
that there is a decreased risk of arterial disease while at the same time an increased the risk for venous thrombosis. Whether a common mechanism of coagulation and inflammation contributes to both responses is unclear. Furthermore, there are two separate phases in venous thrombosis: a significant increase in risk in the short term, with a plausible reduction in risk associated with long-term use.

\section{Arterial disease}

Atherosclerosis is a progressive disease which is characterized by the accumulation of lipids and fibrous elements in the walls of large arteries and constitutes the most important factor in the growing incidence of CAD. Several risk factors, such as cigarette smoking, diabetes, hypertension and elevated serum lipid concentration, have been shown to increase the incidence and accelerate the progression of the disease (Multiple risk factor intervention trial, 1982; Castelli, 1996). Atherosclerosis is responsible for $\mathrm{MI}$ and stroke, as well as for their respective precursor disorders, angina pectoris and transient ischemic cerebral attacks (Born et al., 1991). Atherosclerosis is a focal intimal disease of arteries from the aorta down to vessels of $3 \mathrm{~mm}$ external diameter. However, not all arteries are equally susceptible; the internal mammary artery is mostly unaffected while coronary arteries are at high risk (Davies and Woolf, 1993). The increased risk of MI and ischemic and hemorrhagic stroke associated with oral contraceptive usage appears elevated only in women with hypertension or who smoke, the risk being negligible in the absence of these risk factors.

Clinical symptoms of atherosclerosis depend on four mechanisms: 1) lipid accumulation and connective tissue matrix production can increase plaque volume so that it encroaches on the lumen and impedes blood flow. 2) A plaque can enter an unstable phase and fissure which leads to thrombus formation. The thrombus can encroach or occlude the lumen or, alternatively, embolize, impact and occlude a smaller distal vessel. 3) Although atherosclerosis is a focal disease, it is associated with a generalized abnormality in vascular tone in affected vessels which favors vasoconstriction, especially during stress and exercise. 4) Medial atrophy and destruction can lead to aneurysm formation (Davies and Woolf, 1993).

Many hypothesis of atherogenesis have been proposed. These tend not to be mutually exclusive and differ more in the emphasis given to particular events rather than to opposing points of view. It is well accepted that lipid accumulation in the arterial wall, caused by hyperlipidemia, is the initial step. Recently, advances in cellular and molecular biology have focused on the role of inflammation in atherogenesis (Figure 1). In many animal models, signs of inflammation are observed simultaneously with lipid accumulation. In both experimental animals and humans, blood leukocytes, mediators of the immune response and inflammation, attach to the endothelial cells that line the intima. The normal endothelium does not support the binding of white blood cells. However, soon after the start of an atherogenic diet, endothelial cells begin to express on their surface adhesion molecules capable of binding leukocytes (Huo \& Ley, 2001). Among these adhesion molecules, VCAM1 and ICAM-1 bind monocytes and T lymphocytes found in early atheroma (Steps $1 \& 2$, figure 1) (Libby et al., 2002a, b). Increased VCAM-1 expression is also localized to sites prone to atherogenesis, such as branch points in arteries where endothelial cells are subject to disturbed blood flow (Topper et al., 1996). Serum levels of soluble P-selectin and ICAM-1 are also elevated in patients with peripheral atherosclerotic disease (Huo and Ley, 2001). Abnormal laminar shear stress reduces NO production which in turn increases VCAM-1 expression (De Caterina et al., 1995). Progestins inhibit NO production (Imthurn et al., 1997). It is widely reported that estrogen replacement therapy decreases VCAM-1 expression, thereby providing a potentially-protective mechanism to early atherogenic processes (Nathan \& Chaudhuri, 1997; Seljeflot et 

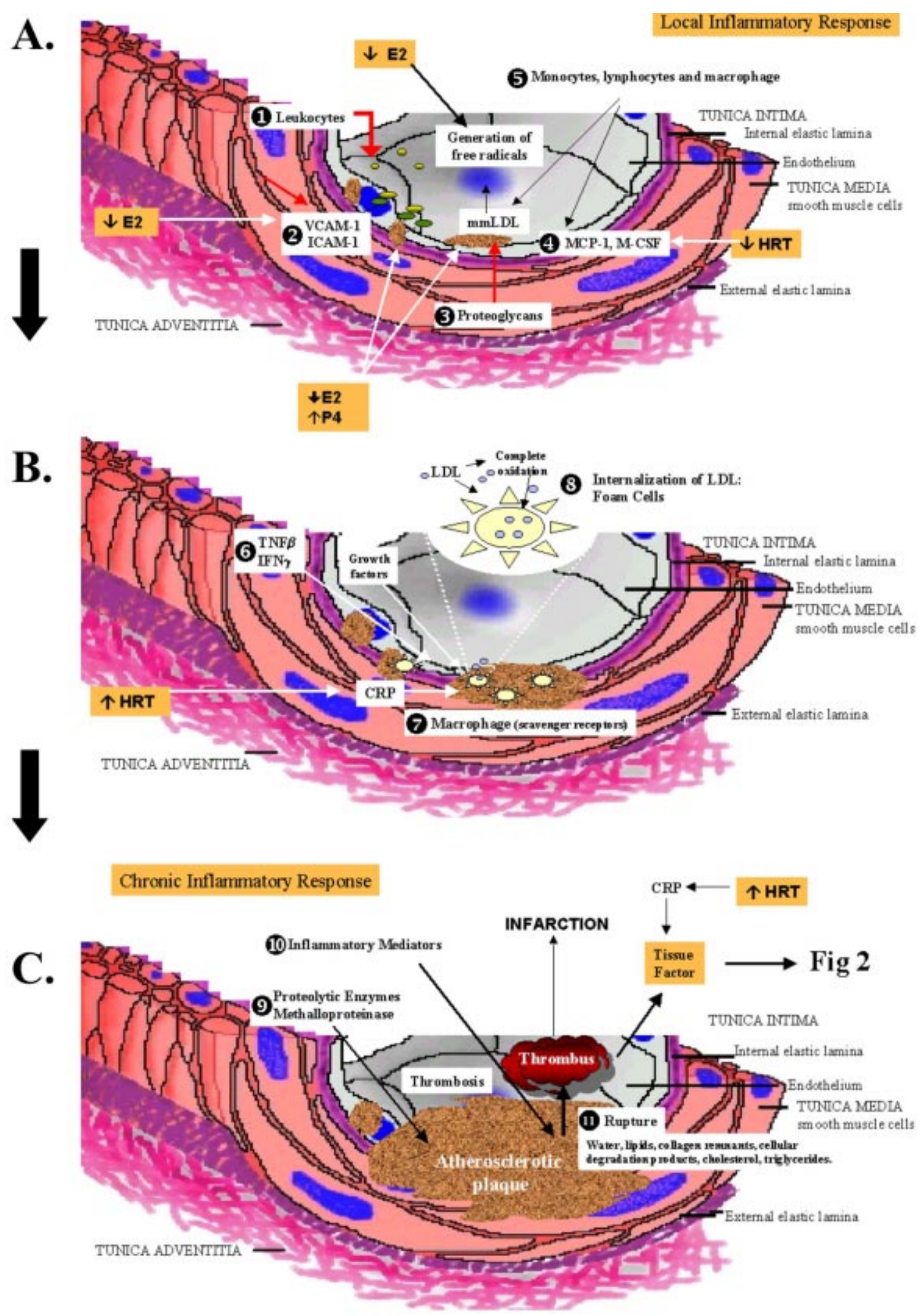

Figure 1. Hormonal effects on the atherogenic process. A. expression of inflammatory and adhesion molecules; initial lipid infiltration and accumulation. B. Plaque growth and increased LDL deposition. C. Plaque rupture and thrombus formation. 
al., 2000; Table I). An increase in reactive oxygen species (ROS) in the endothelium, intima and adventitia also plays a major role in the deposition of LDL. Risk factors, such as hyperhomocysteinemia and smoking, increase the oxidation of LDL (oxLDL) and thus deposition through expression of scavenger receptors in the arterial wall (Harrison et al., 2003). Increased shear stress may also induce formation by VSMC of proteoglycans that bind lipoprotein particles, facilitating their oxidative modification and further inducing an inflammatory response (Lee et al., 2001) (Step 3, figure 1). Once the leukocytes have adhered to the endothelium and an inflammatory response is initiated, monocytes penetrate the intima in response to monocyte chemoattractant protein-1 (MCP-1) (Gu et al., 1998), (Step 4 \& 5, figure 1). Once in the arterial wall, the monocytes differentiate into macrophages in response to macrophage colonystimulating factor (M-CSF) (Step $4 \& 5$, figure 1) (Qiao et al., 1997). Estrogen decreases the expression of MCP-1 and MCSF thereby decreasing monocyte adhesion to endothelial cells and monocyte migration into the subendothelial space (Nathan \& Chaudhuri, 1997). Monocyte adhesion and migration produce a localized inflammatory response in which tumor necrosis factor beta (TNFß) and interferon gamma (INF $\gamma$ ) are released by macrophages (Step 6, figure 1). During this stage, expression of $\mathrm{C}$ reactive protein (CRP), a marker of inflammation, is also increased. Combined estrogen and progesterone therapy increases CRP expression and therefore may further increase the damage induced by the inflammatory response (van Baal et al., 1999b, c; Skouby et al., 2002). These macrophages also have increased expression of the scavenger receptor $A$ and CD36 which internalize modified lipoproteins (minimally modified and oxLDL), accumulating cholesteryl esters in the form of cytoplasmic droplets, leading to foam cell formation which characterize the fatty streak, a hallmark of the early atherosclerotic lesion (Step $7 \& 8$, figure 1) (Libby, 2002a, b). Estrogen also decreases LDL oxidation, thereby preventing foam cell formation and lesion progression (Crook, 2001; Tedeschi-Reiner \& Reiner, 2001; Table I).

Growth factors, inflammatory mediators and proteolytic enzymes released by foam cells induce smooth muscle cell replication, which accumulate in the plaque and lay down extracellular matrix, transforming the fatty streaks into a complicated atheroma. As the lesion grows, it narrows the arterial lumen, interfering with blood-flow and causing clinical symptoms, such as angina pectoris or acute MI (Steps 9-11, figure 1).

This apparently smooth progression of plaque growth is frequently marked by bursts in growth of the atheroma (Yokoya et al., 1999). There is evidence to suggest that physical disruption of plaques may trigger thrombosis and promote sudden

Table I

Beneficial effects of estrogen in the plasma and on the arterial wall

\begin{tabular}{|c|c|c|}
\hline Plasma & Endothelium & Media \\
\hline$\downarrow \mathrm{LDL}$ & $\downarrow$ Proliferation injury & $\downarrow$ Calcification \\
\hline $\boldsymbol{\wedge} \mathrm{HDL}$ & 수 Prostacyclin & † FGF \\
\hline$\downarrow \mathrm{Lp}(\mathrm{a})$ & $\boldsymbol{4} \mathrm{NO}$ & $\downarrow$ ICAM-1 \\
\hline$\downarrow$ Fibrinogen & $\boldsymbol{4}$ eNOS & $\downarrow$ VCAM-1 \\
\hline$\downarrow$ PAI-1 & $\downarrow$ E-selectin & $\downarrow \mathrm{NF} \kappa \mathrm{B}$ \\
\hline$\downarrow$ Platelet aggregation & A Flow-mediated dilatation & $\downarrow \mathrm{O}_{2}$ Formation \\
\hline$\downarrow$ TPA & 个 Acetylcholine dilatation & $\boldsymbol{A}$ Insulin sensitivity \\
\hline$\downarrow \mathrm{TNF} \alpha$ & $\downarrow$ Endothelin & $\downarrow \mathrm{SMC}$ proliferation/migration \\
\hline$\downarrow$ Homocysteine & $\downarrow$ Vasospasm & $\downarrow$ Atherosclerosis \\
\hline
\end{tabular}


expansion of the atheroma (Davies, 1996). The most common mechanism of plaque disruption is a fracture of the plaque's fibrous cap through the elaboration of proteases, such as the matrix-degrading neutral metalloproteinases. This cap serves to separate the thrombogenic lipid-rich core of the atheroma from the bloodstream, which contains coagulation factors. Fissure of the fibrous cap allows contact between coagulation factors and tissue factor (TF), the main pro-thrombotic element in the lipid core, causing blood coagulation. Subsequently, platelets become activated by thrombin, generated by the coagulation cascade and by contact with the intimal compartment, causing thrombus formation. If the thrombus occludes the artery, it can cause an acute MI (Libby, 2002a, b).

\section{HORMONES AND THE COAGULATION PATHWAY}

The intrinsic coagulation pathway starts with injury to the vessel wall, with exposure of sub-endothelial collagen. The first step in this pathway is the conversion of Factor XII to Factor XIIa. The presence of OCs increases the concentration of Factor XII (Gordon et al., 1983). Factor XIIa promotes the activation of Factor XI to Factor XIa, which in turn activates Factor IX. Factor IX has been shown to be increased in women taking HRT (Lowe et al., 2001). HRT preparations have also been associated with a decrease in plasma levels of Factor VIII (Acs et al., 2002). The combination of Factor IXa and Factor VIII promote the activation of Factor X. On the other side, the extrinsic pathway is initiated by the exposure of Tissue Factor (TF) to circulating Factor VII. TF has been extensively reported to be regulated by exogenous ovarian hormone treatments. Holschermann et al. (1999) reported an increase in TF expression by blood monocytes in the presence of OCs that may favor intravascular clotting activation. Furthermore, several HRT preparations have been demonstrated to lower TF levels in the endothelium, but at the same time increase TF/Factor VIIa activity (Koh et al., 2001). The circulating levels of Factor VII are also altered in response to HRT. In short-term studies (up to one year), cyclic regimes of estrogen and progesterone demonstrate that unopposed estrogen increases Factor VII concentration, an effect which was reversed upon addition of progesterone (Bladbjerg et al., 2002; Lowe et al., 2001; Cushman et al., 1999). Other reports have observed a decrease in Factor VII levels after six weeks of combined treatment HRT (Peverill et al., 2001), while others have shown a differing increase in Factor VII depending on the generation of progestin used in OCs (Kluft 2000). The active complex of TF/Factor VIIa is inhibited by tissue factor pathway inhibitor (TFPI) (Badimon et al., 1999). This protein is down-regulated by estrogen and HRT and OC combinations (Bladbjerg et al., 2002; Peverill et al., 2001; Luyer et al., 2001; Harris et al., 1999), leading to the presence of a hypercoagulable state. Proteolytic cleavage resulting in the formation of Factor VIIa leads, in collaboration with TF, to the activation of Factor X (Factor Xa). This conversion point of the intrinsic and extrinsic pathways promotes the conversion of the soluble blood protein prothrombrin to thrombin. Factor $\mathrm{Va}$ also plays a regulatory role in this process. The presence of a mutation in factor $\mathrm{V}$, known as Factor V Leiden, greatly increases the risk of venous thrombosis associated with OCs 30-50 times (Bauer, 2002; Vandenbroucke et al., 2001). Increases in circulating levels of prothrombrin are observed with unopposed estrogen and HRT treatment (Vahkavaara et al., 2001; Peverill et al., 2001, respectively). The net results of these regulations have led to reports of increased levels of thrombin in the presence of estrogen and HRT (Norris et al., 2002; Vahkavaara et al., 2001; Peverill et al., 2001). The amino acid fragment $(F 1+2)$, which is generated during prothrombin activation and thus provides a good indication of thrombin levels, was shown to be increased in the presence of HRT, and these levels were higher in women who subsequently developed recurrent venous thrombosis (Hoibraaten et al., 2001; Cano \& Van Baal, 2001). Thrombin has several roles: firstly to promote the formation of fibrin from fibrinogen; and secondly, to form a complex with thrombomodulin. This 
complex can also down-regulate the circulating levels of thrombin (dashed line with negative sign in Figure 2). In contrast to the above mentioned hormonal regulation of the coagulation cascades, combined estrogen and progestin treatments display anticoagulant activity by lowering the circulating levels of the fibrin precursor fibrinogen (Acs et al., 2002; Cushman et al., 1999; van Baal et al., 1999b; Norris et al., 2002; Table I). HRT has also been reported to increase fibrin turnover (Sidelmann et al., 2003). Finally, in clot formation Factor XIIIa, a transglutaminase, crosslinks the fibrin monomers. The degradation of the clot in the processes leading to fibrinolysis is regulated by sex steroid hormones (Table I). As mentioned above, thrombin forms a complex with thombomodulin which in turn activates Protein C. Reports are contradictory on the effect of hormones on the levels of activated protein C (APC). Some reports demonstrate higher levels in the presence of HRT (Lowe et al., 2001), while others show a reduction (Hoibraaten et al., 2000; Lowe et al., 2001). APC inactivates Factor V, Factor VIIIa (by proteolytic cleavage) and PAI-1. Interestingly, the risk factor, Factor $\mathrm{V}$ Leiden, has diminished sensitivity to APC favoring a coagulation state. In accordance with this effect, elevated Factor VIII levels are associated with an increased risk of deep vein thrombosis (Koster et al., 1995; Kamphuisen et al., 2001). A further anticoagulant action of hormones is demonstrated by both unopposed estrogen (Vahkavaara et al., 2001) and HRT-reducing circulating levels of PAI-1 (Lowe et al., 2001; Koh, 2002; Cushman et al., 1999; Table I). PAI-1 inactivates tissue plasminogen activator (t-PA) and plasminogen activator type-urokinase (uPA). The conversion of plasminogen to plasmin, which participates in fibrinolysis, is regulated by both u-PA and by t-PA. Interestingly, at this stage, hormones create a balance between promoting and reducing plasmin levels. Levels of plasminogen are increased by both estrogen (Luyer et al., 2001) and HRT (Acs et al., 2002), while tPA levels have been reported to be reduced by estrogen (Vahkavaara et al., 2001) and
HRT (Lowe et al., 2001; Koh, 2002). However, Hoetzer et al. (2003) reported that estrogen could increase t-PA levels $30 \%$ compared to controls, while the addition of progesterone, in HRT, reversed this effect. As it is clear that hormones have a strong procoagulative role (on the generation of thrombin) and that there exists a fine hormonal balance in the promotion or inhibition of fibrinolysis, depending on the regime and dosage, hormones may increase or decrease the coagulative potential and thus impose either positive or negative effects on cardiovascular disease.

\section{COAGULATION AND CAD}

\section{Coagulation and venous thrombosis}

Estrogen and combined estrogen and progestin exogenous preparations alter the coagulable state (reviewed in Figure 2). An increase in the concentration of blood procoagulants may initiate clotting and lead to thrombosis formation increasing the risk of venous thrombosis. This clot may disengage from the vessel wall and flow, via the right side of the heart, to the pulmonary arteries causing pulmonary embolism. The increase in venous thrombosis risk is concentrated in the first year of treatment. As demonstrated in Figure 2 and the accompanying text, exogenous hormones maintain a delicate balance between pro- and anti-coagulative states. To date there is insufficient clinical data relating to the levels of coagulation cascade intermediates to draw firm conclusions, but initial reports suggest there may be an increase in fibrinolytic activity with duration of hormonal usage (Salobir et al., 2002).

\section{Coagulation and atherosclerosis}

Clotting at the site of the lesion may involve both the intrinsic and extrinsic coagulation pathways (Khrenov et al., 2002a). The extrinsic, TF-dependent, pathway plays a major role in determining the thrombogenicity of atherosclerotic lesions 
and subsequent generation of acute coronary syndromes (Toschi et al., 1997). In the normal vessel, TF is not expressed on endothelial cells or monocytes which are exposed to the circulating blood. TF is restricted to the adventitia and VSMC of the media (Wilcox et al., 1989). However, in atherosclerotic lesions, high levels of TF mRNA and protein can be found in all three cell types which make up the vessel wall (Moreno et al., 1996). Furthermore, TF expression levels have a high degree of correlation with plaque severity and vulnerability (Ardissino et al., 1997).

Although the extrinsic pathway is responsible for the initiation of thrombus formation, there is mounting evidence that it is solely responsible for the occlusive thrombus formation (Sramek et al., 2001; Bilora et al., 2001; Rosendaal et al., 1990; Triemstra et al., 1995). This implies that the intrinsic pathway, which activates factor $\mathrm{X}$ 50-fold more efficiently and amplifies the coagulation triggered by the TFdependent pathway (Mann, 1999), also contributes to thrombogenicity of the atherosclerotic lesion.

Recent evidence indicates that the LDL/ HDL ratio may also affect coagulation. Increased LDL concentrations have a procoagulant effect (Moyer et al., 1998) whereas HDL acts as an anticoagulant (Griffin et al., 1999). The mechanism responsible for these effects seems to be lipoproteins providing a phospholipid surface where the assembly of enzymatic complexes of the coagulation cascade can take place. Specifically, VLDL and oxLDL can support prothrombinase activity and LDL supports extrinsic and intrinsic Xase activity (Khrenov et al., 2002b). While the ability of lipoproteins to support coagulation complex assembly is far less than that observed in platelets, enriched LDL and oxLDL present in the lipid-rich core may play an important role in Xase

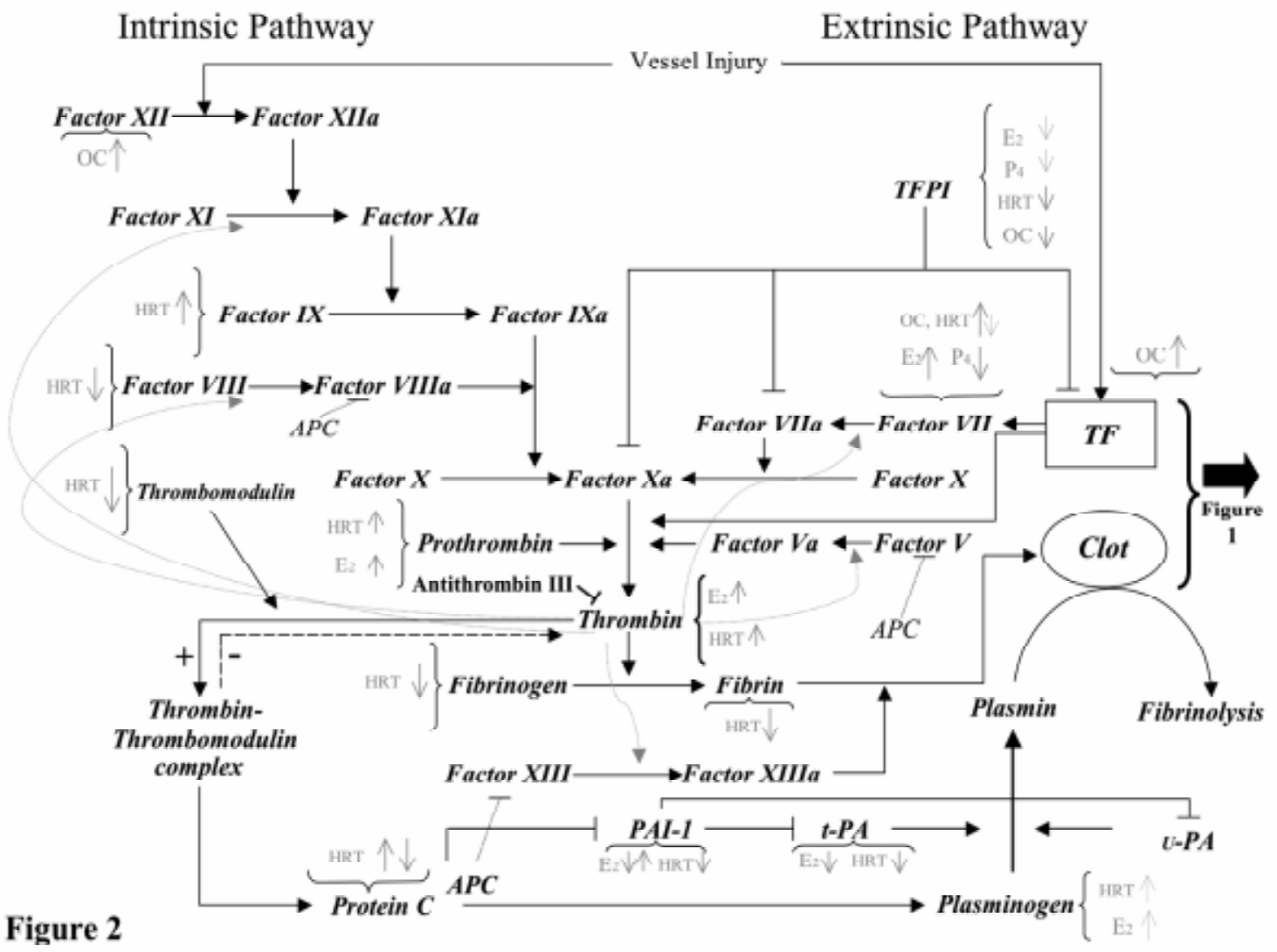

Figure 2. Hormonal effects on the coagulation cascade. 
and prothombinase complex assembly, adding to the thrombogenicity of the lesion. As mentioned above, estrogen decreases LDL and increases HDL levels, while progestins have the opposite effect.

The accumulation of oxLDL within the plaque induces pathological changes in all vessel wall cells, increasing thrombogenesis (Khrenov et al., 2002a). Oxidized LDL induces TF expression in endothelial cells (Fei et al., 1993), macrophages (Brand et al., 1994) and VSMC (Penn et al., 2000). Accumulated oxLDL may also enhance the ability of atherosclerotic lesion cells to form the phospholipid surface required for the assembly and activity of enzymatic complexes of the intrinsic pathway. Exposure of human macrophages and VSMC to oxLDL increases their ability to support Xase and prothrombinase complex activity, greatly increasing thrombin formation (Ananyeva et al., 2002). This increase in intrinsic pathway procoagulant activity is related to increased expression of factor VIII binding sites and more efficient assembly of Xase complex due to increased exposure of phosphatidylserine (PS) on oxLDL-treated cells (Wintergerst et al., 2000). This data indicates that the intrinsic pathway may play an important role in upregulating the thrombogenicity of atherosclerotic lesions following endothelial layer removal and subsequent exposure of VSMC and macrophages to blood flow.

Although apoptotic cells are absent from normal arteries, they are common in advanced plaques and include VSMC, macrophages and $\mathrm{T}$ lymphocytes (Bjorkerud \& Bjorkerud, 1996). Apoptosis can be induced by a variety of agents; however, apoptosis is probably mediated by oxLDL within the plaque (Okura et al., 2000). One of the characteristics of apoptotic cells is the translocation of PS from the inner to the outer surface of the plasma membrane by a loss of membrane phospholipid asymmetry. The increased expression and accessibility of PS on the outer surface of the plasma membrane increases the thrombogenic potential of these cells by providing a platform for the assembly of complexes of both intrinsic and extrinsic coagulation pathways (Gilbert \& Arena, 1996). Another thrombogenic effect of apoptotic cells present in the plaque is the shedding of PS- and TF-rich microparticles (Mallat et al., 1999; Bombeli et al., 1997).

Thrombogenicity is related to upregulation of both intrinsic and extrinsic pathways. However, down-regulation of anticoagulant and fibrinolytic activity may also contribute to atherothrombosis (Khrenov et al., 2002a). Oral contraceptives have been demonstrated to lower the sensitivity of factors involved in thrombin generation to APC, thus promoting a more coagulative state (reviewed in Cano \& Van Baal, 2001). There is further evidence which shows that thrombomodulin and the endothelial cell protein $\mathrm{C}$ receptor expression are down-regulated in atherosclerotic plaques (Laszik et al., 1994). Since HDL increases protein $C$ activity, this down-regulation may be associated with decreased HDL levels observed in atherosclerosis (Griffin et al., 1999).

THE BENEFITS AND THE RISKS OF EXOGENOUS HORMONES IN ARTERIAL DISEASE

The paradox of why exogenous hormones increase the short-term risk of cardiovascular disease yet may lower longterm evident risk may be related to the nature of the genesis of venous thrombosis and MI. MI is a consequence of atherosclerosis, while venous thrombosis is a disease of the veins which arises from hypercoagulation and venous stasis. Arteries are larger than veins and have greater flexibility brought about presence of an elastic layer. Movement of the wall of the endothelium is maintained by a delicate balance of dilating factors, such as NO and bradykinin, in combination with constricting factors, such as angiotensinII, thromboxane, and endothelin among others (reviewed in Cano \& Van Baal, 2001). These may be contributing factors as to why arterial disease and myocardial infarction have a lower incidence than venous thrombosis. Another important 
Scenario A. Women without risk factors using HRT
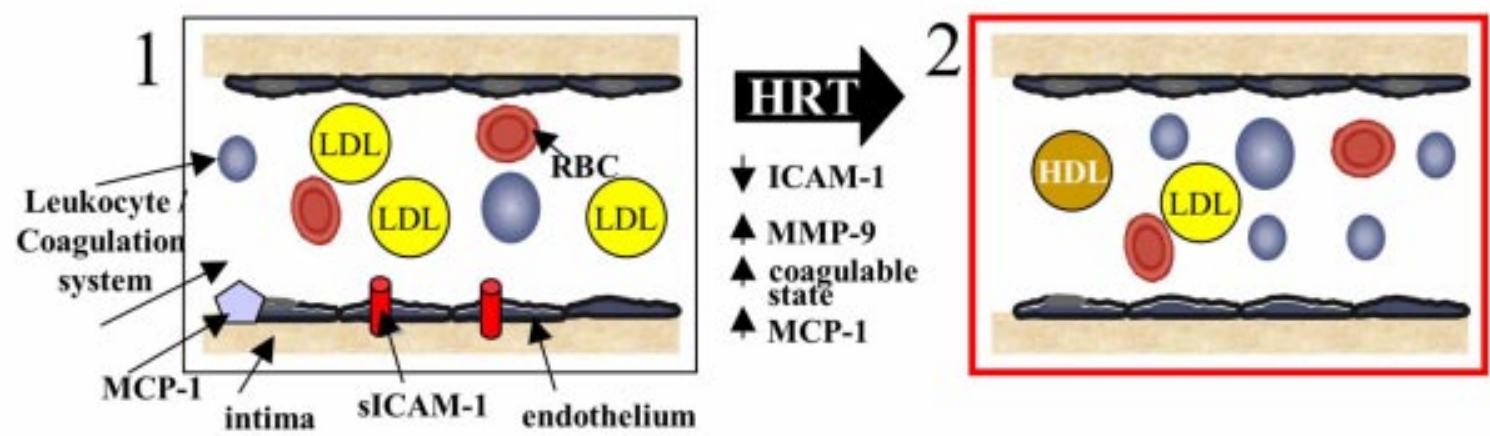

Scenario B. Woman with risk factors using HRT
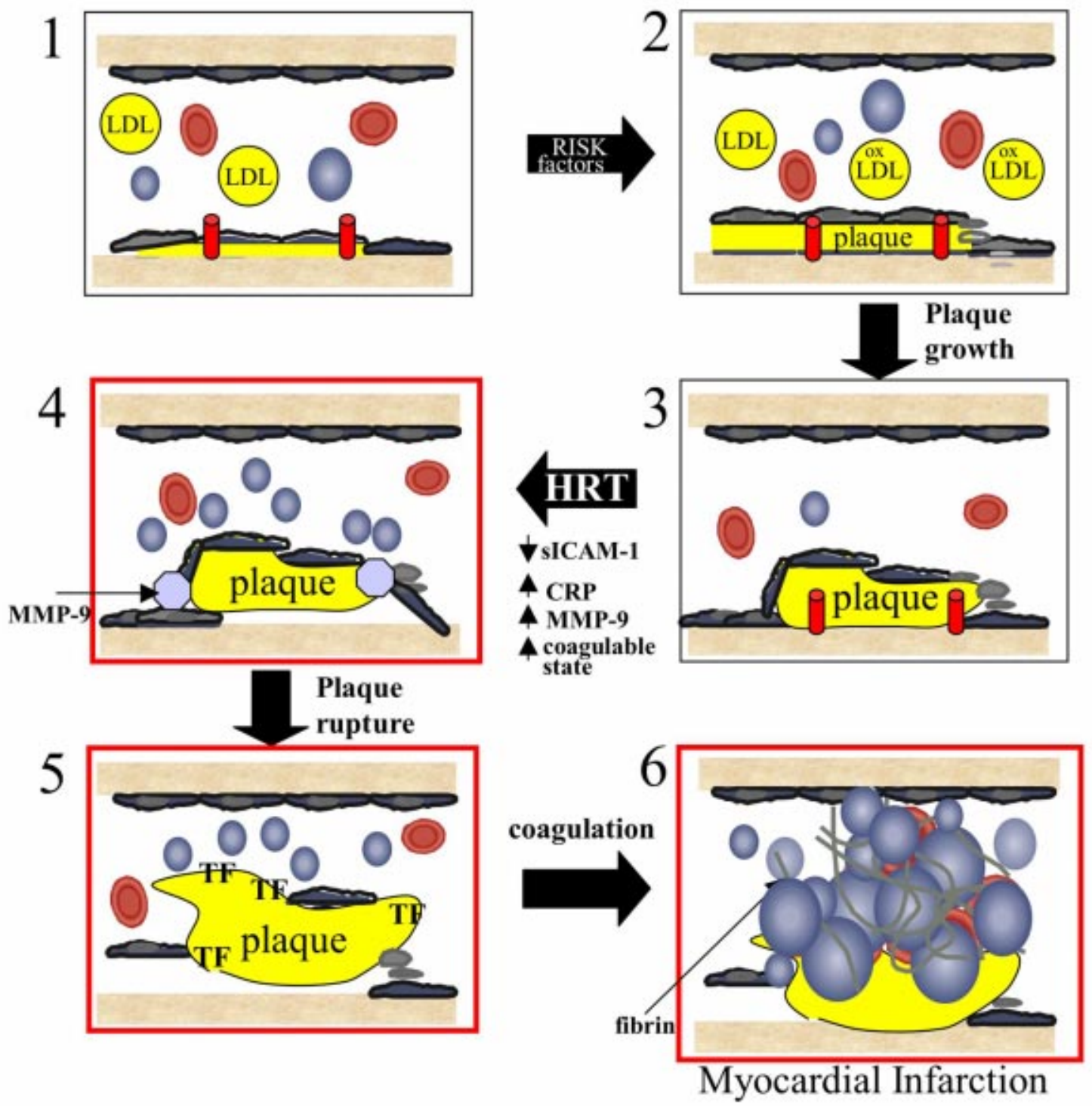

Figure 3. Role of hormone replacement therapy (HRT) in atherogenesis in women with and without cardiovascular risk factors. 
factor is the process of atherogenesis which occurs only in the arteries. As previously mentioned, exogenous hormones only increase the risk of MI in the presence of cardiovascular risk factors. As depicted in Figure 3 (Scenario A) using HRT as an example in women with no risk factors the increase in blood procoagulants (hypercoagulative state) will not lead to thrombosis formation, due to the size and movement of the artery, and thus the beneficial effects of estrogen in preventing the formation of an atherosclerotic plaque may provide long-term protection against MI and stroke. These beneficial effects of exogenous hormones include: 1) lowering LDL and raising HDL (Table I); 2) reducing intimal damage on vessel walls (Table I); 3) lowering the expression of adhesion molecules such as E-selectin and SICAM-1 (Van Baal et al., 1999a; Table I); 4) lowering MCP-1 (Stork et al., 2002) and (5) increasing anticoagulant APC activity.

However, when women combine exogenous hormones with previous cardiovascular risk factors, an increase in risk of MI is observed (Figure 3, Scenario B). In this case, a risk factor such as hypertension facilitates incorporation of LDL into the arterial wall (Medina et al., 1997), the first step in the formation of an atherosclerotic plaque. This step is further confounded by smoking, which leads to the oxidation of LDL and thus enhanced deposition. Once an atherosclerotic plaque is formed (or is already present), the lowering by estrogens and/or HRT of soluble ICAM-1 and E-selectin and the increasing levels of CRP and matrix metalloproteinase-9 (MMP-9) will destabilize the plaque (Cano \& Van Baal, 2001; Stork et al., 2002; Piercy et al., 2002; Zanger et al., 2000). When rupture of the atherosclerotic plaque occurs, a process which is also promoted by hypertension, the coagulation cascade is initiated. In this instant, the increased presence of TF, and other factors, that exist in the presence of exogenous hormones will promote coagulation and increase the clotting potential, leading to more rapid and greater clot formation and thus thrombosis and MI (Figure 3). If thromboembolism, occurs a high change of stroke will ensue. In support of a hypercoagulable state being a risk factor only in the presence of an atherosclerotic plague, which is deposited more frequently in the presence of the above-mentioned risk factors, markers of coagulation and fibrinolysis (such as t-PA, PAI-1 fibrinogen, and D-dimer) are not associated with increased risk of myocardial infarction, but are associated with atherosclerosis (Haverkate, 2002).

\section{THE FUTURE OF EXOGENOUS HORMONES}

The small increase in CAD in women using OCs does not outweigh the benefits from avoiding the trauma and complications arising from unwanted pregnancies, especially in non-smokers with no prior history or cardiovascular risk factors. Along with beneficial effects on mood, osteoporosis and hot flushes, the HRT preparations were to be a simple and safe prophylactic for heart disease. This idea is based on apparently foolproof logic: premenopausal women have lower CAD, take away the hormones at menopause and the protection is lost, add back the hormones and we get back the protection. What may have appeared to be simple on paper has proved to be a nightmare in the clinic. Women are now facing the scenario that not only are their HRT preparations not delivering a protective effect, but that these preparations may actually be putting them at higher risk for CAD (certainly in the short term).

Unfortunately, there are a number of variables queuing up for consideration. First, we have no evidence that if women never went through menopause, that they would maintain the cardiovascular protection as they grow older, since changes in the coagulation system are known to occur naturally with the aging process. Second, although women develop CAD about ten years later than men, they are likely to fare worse after a heart attack (Giardina, 2000). Third, the hormone regimes given as HRT can never exactly mimic the circulating balance and concentrations present in premenopausal 
women. Neither will exogenous hormones emulate the specificity of in vivo action derived from the local expression of hormones.

Although an in vivo premenopausal situation is never truly possible, the future of HRT is not dead. The beneficial effects of exogenous hormones are required by a subset of women, and as life expectancy increases with every generation, the postmenopausal phase will account for an ever-increasing portion of a woman's life.

The negative results from the Women's Health Initiative study (WassertheilSmoller et al., 2003) may reflect the combination of risk factors, such as smoking, with hormonal preparations. In the Women's Health Initiative trial, $50 \%$ of the women on HRT had smoked before or continued to smoke during the study (Mueck \& Seeger, 2003). Estrogen turnover is increased in women who smoke, reducing the beneficial estrogenic actions (Mueck \& Seeger, 2003).

Through the vast array of data regarding OCs, HRT and cardiovascular disease, a beneficial effect or at the very least an insurance of no increased CAD risk, does appear to be present under tightly-defined parameters. It is evident from these clinical studies that the choice of exogenous hormone, combined with personal history and the presence of cardiovascular risk factors need to be taken into consideration before prescription. The feasibility of screening for CAD risk factors may have to be considered. Although the results are not fully clear on the effects of HRT on CAD in healthy, risk-factor-free women, the data does suggest that HRT should not be prescribed, at present, for the prevention of cardiovascular disease. In regard to preparation and dosage, Rosendaal et al. (2002) recommend that contraceptives with $30 \mathrm{ug}$ ethinyl estradiol should be the first choice and that third-generation progestins should be avoided due to their association with increased venous thrombosis.

The information accumulated to date has mainly concentrated on estrogens as a major risk factor, but increasing evidence supports a role for progestins in pathogenesis. The objectives now facing the scientist and the clinician is to better understand the workings, at the physiological and molecular level, of estrogen and progesterone and to determine where and when hormones are required and apply them accordingly. Hopefully, the foolproof plan was merely naive in its execution, while the logic is still firmly in place.

\section{ACKNOWLEDGEMENTS}

Partially supported by grant 89/01 (R.A.M) from the Dirección de Investigación, Universidad Nacional Andrés Bello, Santiago, Chile and grant number 1020715 from FONDECYT, Chile (G.I.O).

\section{REFERENCES}

ACS N, VAJO Z, MIKLOS Z, SIKLOSI G, PAULIN F, FELICETTA JV, SZEKACS B (2002) The effects of postmenopausal hormone replacement therapy on hemostatic variables: a meta-analysis of 46 studies. Gynecol Endocrinol 16: 335-346

ADAMS MR, KAPLAN JR, MANUCK SB, KORITNIK DR, PARKS JS, WOLFE MS, CLARKSON TB (1990) Inhibition of coronary artery atherosclerosis by $17 \mathrm{~B}-$ estradiol in ovariectomized monkeys: Lack of an effect of added estrogen. Arteriosclerosis 10: 1051-1057

ADAMS MR, REGISTER TC, GOLDEN DL, WAGNER JD, WILLIAMS JK (1997) Medroxyprogesterone acetate antagonizes inhibitory effects of conjugated equine estrogens on coronary artery atherosclerosis. Arterioscler Throm Vasc Biol 17: 217-221

ANANYEVA NM, KOUIAVSKAIA DV, SHIMA M, SAENKO EL (2002) Intrinsic pathway of blood coagulation contributes to thrombogenicity of atherosclerotic plaque. Blood 99: 4475-4485

ARDISSINO D, MERLINI PA, ARIENS R, COPPOLA R, BRAMUCCI E, MANNUCCI PM (1997) Tissue-factor antigen and activity in human coronary atherosclerotic plaques. Lancet 349: 769-771

BADIMON JJ, LETTINO M, TOSCHI V, FUSTER V, BERROZPE M, CHESEBRO JH, B ADIMON L (1999) Local inhibition of tissue factor reduces the thrombogenicity of disrupted human atherosclerotic plaques: effects of tissue factor pathway inhibitor on plaque thrombogenicity under flow conditions. Circulation 99: 1780-1787

BAUER KA (2002) Hormone replacement therapy and the factor V Leiden mutation. Arterioscler Thromb Vasc Biol 22: 879-880

BERGER GS, FOWLER WC (1997) Exogenous estrogens and endometrial carcinoma: review and comments for the clinician. J Reprod Med 18: 177-180

BILORA F, BOCCIOLETTI V, ZANON E, PETROBELLI F, GIROLAMI A (2001) Hemophilia A, von Willebrand disease, and atherosclerosis of abdominal aorta and leg arteries: factor VIII and von Willebrand factor defects appear to protect abdominal aorta and leg arteries from atherosclerosis. Clin Appl Thromb Hemost 7: 311-313 
BJORKERUD S, BJORKERUD B (1996) Apoptosis is abundant in human atherosclerotic lesions, especially in inflammatory cells (macrophages and T cells), and may contribute to the accumulation of gruel and plaque instability. Am J Pathol 149: 367-380

BLADBJERG EM, SKOUBY SO, ANDERSEN LF, JESPERSEN J (2002) Effects of different progestin regimens in hormone replacement therapy on blood coagulation factor VII and tissue factor pathway inhibitor. Hum Reprod 17: 3235-3241

BLOEMENKAMP KW, HELMERHORST FM, ROSENDAAL FR, VANDENBROUCKE JP (2003) Thrombophilias and gynaecology. Best Pract Res Clin Obstet Gynaecol 17: 509-528

BLOEMENKAMP KW, ROSENDAAL FR, HELMERHORST FM, VANDENBROUCKE JP (2000) Higher risk of venous thrombosis during early use of oral contraceptives in women with inherited clotting defects. Arch Intern Med 160: 49-52

BOMBELI T, KARSAN A, TAIT JF, HARLAN JM (1997) Apoptotic vascular endothelial cells become procoagulant. Blood 89: 2429-2442

BORN GVR, TIGGLE DJ, POOLE-WILSON PA (1991) Calcium and atherosclerosis. In: BORN GVR, TIGGLE DJ, POOLE-WILSON PA (eds) Calcium Antagonism and Atherosclerosis. London: Science Press. pp: $1-25$

BRAND K, BANKA CL, MACKMAN N, TERKELTAUB RA, FAN ST, CURTISS LK (1994) Oxidized LDL enhances lipopolysaccharide-induced tissue factor expression in human adherent monocytes. Arterioscler Thromb 14: 790-797

CANO A, VANBAAL WM (2001) The mechanisms of thrombotic risk induced by hormone replacement therapy. Maturitas 40: 17-38

CASTELLI WP (1996) Lipids, risk factors and ischemic heart disease. Atherosclerosis 124: S1-S9

CAULIN-GLASER T, GARCIA-CARDENA G, SARREL P, SESSA WC, BENDER JR (1997) 17ß-estradiol of human endothelial cell basal nitric oxide release, independent of cytosolic $\mathrm{Ca}^{2+}$ mobilization. Circ Res 81: 855-892

CROOK D (2001) Do we need clinical trials to test the ability of transdermal HRT to prevent coronary heart disease? Curr Control Trials Cardiovasc Med 2: 211-214

CUSHMAN M, MEILAHN EN, PSATY BM, KULLER LH, DOBS AS, TRACY RP (1999) Hormone replacement therapy, inflammation, and hemostasis in elderly women. Arterioscler Thromb Vasc Biol 19: 893-899

DAVIES MJ (1996) Stability and instability: the two faces of coronary atherosclerosis. The Paul Dudley White Lecture, 1995. Circulation 94: 2013-2020

DAVIES MJ, WOOLF N (1993) Atherosclerosis: what is it and why does it occur? Br Heart J 69: S3-S11

DECATERINA R, LIBBY P, PENG HB, THANNICKAL VJ, RAJAVASHISTH TB, GIMBRONE MA, SHIN WS, LLAO JK (1995) Nitric oxide decreases cytokineinduced endothelial activation. Nitric oxide selectively reduces endothelial expression of adhesion molecules and proinflammatory cytokines. J Clin Invest 96: 60-68

DOUGLAS PS, KATZ SE, WEINBERG EO, CHEN MH, BISOP SP, LORELL BH (1998) Hypertrophic remodeling: gender differences in early response to left ventricular pressure overload. J Am Coll Cardiol 32: $1118-1125$
DUBAL DB, ZHU H, YU J, RAU SW, SHUGHRUE PJ, MERCHENTHALER I, KINDY MS, WISE PM (2001) Estrogen receptor $\alpha$, not $\beta$, is a critical link in estradiolmediated protection against brain injury. Proc Natl Acad Sci USA 98: 1952-1957

ESPELAND MA, MARCOVINA SM, MILLER V, WOOD PD, WASILAUSKAS C, SHERWINR, SCHROTT H, BUSH TL (1998) Effect of postmenopausal hormone therapy on lipoprotein(a) concentration. PEPI investigators. Postmenopausal estrogen/progestin interventions. Circulation 97: 979-986

FARMER RD, LAWRENSON RA (1998) Oral contraceptives and venous thromboembolic disease: the findings from database studies in the United Kingdom and Germany. Am J Obstet Gynecol 179: S78-86

FEI H, BERLINER JA, PARHAMI F, DRAKE TA (1993) Regulation of endothelial cell tissue factor expression by minimally oxidized LDL and lipopolysaccharide. Arterioscler Thromb 13: 1711-1717

GIARDINA EG (2000) Heart disease in women. Int J Fertil Womens Med. 45: 350-357

GILBERT GE, ARENA AA (1996) Activation of the factor VIIIa-factor IXa enzyme complex of blood coagulation by membranes containing phosphatidyl-L-serine. J Biol Chem 271: 11120-11125

GORDON EM, DOUGLAS J, RATNOFF OD (1983) Influence of augmented Hageman factor (Factor XII) titers on the cryoactivation of plasma prorenin in women using oral contraceptive agents. J Clin Invest 72: 1833-1838

GRIFFIN JH, KOJIMA K, BANKA CL, CURTISS LK, FERNANDEZ JA (1999) High-density lipoprotein enhancement of anticoagulant activities of plasma protein S and activated protein C. J Clin Invest 103: 219-227

GU L, OKADA Y, CLINTON SK, GERARD C, SUKHOVA GK, LIBBY P, ROLLINS BJ (1998) Absence of monocyte chemoattractant protein-1 reduces atherosclerosis in low-density lipoprotein receptordeficient mice. Mol Cell 2: 275-281

GUETTA V, CANNON RO (1996) Cardiovascular effects of estrogen and lipid-lowering therapies in postmenopausal women. Circulation 93: 1928-1937

HAARBO J, SVEDSEN OL, CHRISTIANSEN C (1991) Estrogen monotherapy and combined estrogenprogestin replacement therapy attenuate aortic accumulation of cholesterol in ovariectomized cholesterol-fed rabbits. J Clin Invest 87: 274-279

HARRIS GM, STENDT CL, VOLLENHOVEN BJ, GAN TE, TIPPING PG (1999) Decreased plasma tissue factor pathway inhibitor in women taking combined oral contraceptives. Am J Hematol 60: 175-180

HARRISON DG, CAI H, LANDMESSER U, GRIENDLING KK (2003) Interactions of angiotensin II with $\mathrm{NAD}(\mathrm{P}) \mathrm{H}$ oxidase, oxidant stress and cardiovascular disease. J Renin Angiotensin Aldosterone Syst 4: 51-61

HANKE H, HANKE S, BRUCK B, BREHME U, GUGEL N, FINKING G, MUCK AO, SCHMAHL FW, HOMBACH V, HAASIS R (1996) Inhibition of the protective effect of estrogen by progesterone in experimental atherosclerosis. Atherosclerosis 121: 129-138

HAVERKATE F (2002) Levels of haemostatic factors, arteriosclerosis and cardiovascular disease. Vascul Pharmacol 39: 109-112 
HISHIKAWA K, NAKAKI T, MARUMO T, SUZUKI H, KATO R, SARUTA T (1995) Upregulation of nitric oxide synthase by estradiol in human aortic endothelial cells. FEBS lett 360: 291-293

HO KJ, LIAO JK (2002) Nonnuclear actions of estrogen. Arterioscler Thromb Vasc Biol 22: 1952-1961

HOETZER GL, STAUFFER BL, IRMIGER HM, NG M, SMITH DT, DESOUZA CA (2003) Acute and chronic effects of oestrogen on endothelial tissue-type plasminogen activator release in postmenopausal women. J Physiol. [in press]

HOIBRAATEN E, OS I, SELJEFLOT I, ANDERSEN TO, HOFSTAD A, SANDSET PM (2000) The effects of hormone replacement therapy on hemostatic variables in women with angiographically verified coronary artery disease: results from the estrogen in women with atherosclerosis study. Thromb Res 98: 19-27

HOIBRAATEN E, QVIGSTAD E, ANDERSEN TO, MOWINCKEL MC, SANDSET PM (2001) The effects of hormone replacement therapy (HRT) on hemostatic variables in women with previous venous thromboembolism-results from a randomized, double-blind, clinical trial. Thromb Haemost 85: 775781

HOLSCHERMANN H, TERHALLE HM, ZAKEL U, MAUS U, PARVIZ B, TILLMANNS H, HABERBOSCH W (1999) Monocyte tissue factor expression is enhanced in women who smoke and use oral contraceptives. Thromb Haemost 82: 1614-1620

HULLEY S, GRADY D, BUSH T, FURBERG C, HERRINGTON D, RIGGS B, VITTINGHOFF E (1998) Randomized trial of estrogen plus progestin for secondary prevention of coronary heart disease in postmenopausal women. Heart and Estrogen/progestin Replacement Study (HERS) Research Group. JAM. 280: 605-613

HUO Y, LEY K (2001) Adhesion molecules and atherogenesis. Acta Physiol Scand 173: 35-43

IAFRATI MD, KARAS RH, ARONOVITZ M, KIM S, SULLIVAN TR, LUBAHN DB, ODONNELL TF, KORACH KS, MENDELSOHN ME (1997) Estrogen inhibits the vascular injury response in estrogen receptor $\alpha$-deficient mice. Nat Med 3: 545-548

IMTHURN B, ROSSELLI M, JAEGER AW, KELLER PJ, DUBEY RK (1997) Differential effects of hormonereplacement therapy on endogenous nitric oxide (nitrite/nitrate) levels in postmenopausal women substituted with $17 ß$-estradiol valerate and cyproterone acetate or medroxyprogesterone acetate. J Clin Endocrinol Metab 82: 388-394

KAMPHUISEN PW, EIKENBOOM JC, ROSENDAAL FR, KOSTER T, BLANN AD, VOS HL, BERTINA RM (2001) High factor VIII antigen levels increase the risk of venous thrombosis but arenot associated with polymorphisms in the von Willebrand factor and factor VIII gene. Br J Haematol 115: 156-158

KHRENOV AV, ANANYEVA NM, GRIFFIN JH, SAENKO EL (2002a) Coagulation pathways in atherothrombosis. Trends Cardiovasc Med 12: 317 324

KHRENOV AV, SARAFANOV A, ANANYEVA N, KOUIAVSKAIA D, SHIMA M, SCHWINN H, JOSIC D, SAENKO E (2002b) Molecular basis for different ability of low-density and high-density lipoproteins to support activity of the intrinsic Xase complex. Thromb Res 105: 87-93
KLUFT C (2000) Effects on haemostasis variables by second and third generation combined oral contraceptives: a review of directly comparative studies. Curr Med Chem 7: 585-591

KOH KK (2002) Effects of hormone replacement therapy on coagulation and fibrinolysis in postmenopausal women. Int J Hematol 76 Suppl 2: 44-46

KOH KK, JIN DK, YANG SH, LEE SK, HWANG HY, KANG MH, KIM W, KIM DS, CHOI IS, SHIN EK (2001) Vascular effects of synthetic or natural progestagen combined with conjugated equine estrogen in healthy postmenopausal women. Circulation 103: 1961-1966

KOSTER T, BLANN AD, BRIET E, VANDENBROUCKE JP, ROSENDAAL FR (1995) Role of clotting factor VIII in effect of von Willebrand factor on occurrence of deep-vein thrombosis. Lancet 345: 152-155

KNOPP RH (1997) Estrogen, female gender, and heart disease. In: Topol E, Ed. Textbook of cardiovascular medicine: Preventive cardiology. New York: Lippincott-Raven, pp:195-218

LASZIK Z, CARSON CW, NADASDY T, JOHNSON LD, LERNER MR, BRACKETT DJ, ESMON CT, SILVA FG (1994) Lack of suppressed renal thrombomodulin expression in a septic rat model with glomerular thrombotic microangiopathy. Lab Invest 70: 862-867

LEE RT, YAMAMOTO C, FENG Y, POTTER-PERIGO S, BRIGGS WH, LANDSCHULZ KT, TURI TG, THOMPSON JF, LIBBY P, WIGHT TN (2001) Mechanical strain induces specific changes in the synthesis and organization of proteoglycans by vascular smooth muscle cells. J Biol Chem 276: 13847 13851

LIBBY P (2002a) Inflammation in atherosclerosis. Nature 420: $868-874$

LIBB Y P, RIDKER PM, MASERI A (2002b) Inflammation and atherosclerosis. Circulation 105: 1135-1143

LINDER V, KIM SK, KARAS RH, KUIPER GG, GUSTAFSSON JA, MENDELSOHN ME (1998) Increased expression of estrogen receptor- $\beta$ mRNA in male blood vessels after vascular injury. Circ Res 83: $224-229$

LOWE GD, UPTON MN, RUMLEY A, MCCONNACHIE A, OREILLY DS, WATT GC (2001) Different effects of oral and transdermal hormone replacement therapies on factor IX, APC resistance, t-PA, PAI and C-reactive protein-a cross-sectional population survey. Thromb Haemost 86: 550-556

LUYER MD, KHOSLA S, OWEN WG, MILLER VM (2001) Prospective randomized study of effects of unopposed estrogen replacement therapy on markers of coagulation and inflammation in postmenopausal women. J Clin Endocrinol Metab 86: 3629-3634

MALLAT Z, HUGEL B, OHAN J, LESECHE G, FREYSSINET JM, TEDGUI A (1999) Shed membrane microparticles with procoagulant potential in human atherosclerotic plaques: a role for apoptosis in plaque thrombogenicity. Circulation 99: 348-353

MANN KG (1999) Biochemistry and physiology of blood coagulation. Thromb Haemostasis 82: 165-174

MEDINA R, CARDONA-SANCLEMENTE LE, BORN GVR, BROWN MJ (1997). Effect of deoxycorticosterone acetate (DOCA) on blood pressure in relation to accumulation of low density lipoprotein and fibrinogen by aorta and other tissues of normotensive Wistar rats. J Hypertens 15: 531-536 
MENDELSOHN ME, KARAS RH (1999) The protective effects of estrogen on the cardiovascular system. N Eng J Med 340: 1801-1811

MORENO PR, BERNARDI VH, LOPEZ-CUELLAR J, MURCIA AM, PALACIOS IF, GOLD HK, MEHRAN R, SHARMA SK, NEMERSON Y, FUSTER V, FALLON JT (1996) Macrophages, smooth muscle cells, and tissue factor in unstable angina. Implications for cell-mediated thrombogenicity in acute coronary syndromes. Circulation 94: 3090-3097

MOYER MP, TRACY RP, TRACY PB, VANTVEER C, SPARKS CE, MANN KG (1998) Plasma lipoproteins support prothrombinase and other procoagulant enzymatic complexes. Arterioscler Thromb Vasc Biol 18: $458-465$

MUECK AO, SEEGER H (2003) Smoking, estradiol metabolism and hormone replacement therapy. Arzneimittelforschung 53: 1-11

MULTIPLE RISK FACTOR INTERVENTION TRIAL RESEARCH GROUP (1982) Multiple risk factor intervention trial intervention trial: risk factor changes in mortality results. JAMA 248: 1465-1470

MURRAY CJ, LOPEZ AD (1997) Global mortality, disability, and the contribution of risk factors: Global Burden of Disease Study. Lancet 349: 1436-1442

NATHAN L, CHAUDHURI G (1997) Estrogens and atherosclerosis. Annu Rev Pharmacol Toxicol 37: 477-515

NODE K, KITAKAZE M, KOSAKA H, MINAMINO T, FUNAYA H, HORI M (1997) Amelioration of ischemiaand reperfusion-induced myocardial injury by $17 ß-$ estradiol: the role of nitric oxide and calcium-activated potassium channels. Circulation 96: 1953-1963

NORRIS LA, JOYCE M, OKEEFFE N, SHEPPARD BL, BONNAR J (2002) Haemostatic risk factors in healthy postmenopausal women taking hormone replacement therapy. Maturitas 43: 125-133

OKURA Y, BRINK M, ITABE H, SCHEIDEGGER KJ, KALANGOS A, DELAFONTAINE P (2000) Oxidized low-density lipoprotein is associated with apoptosis of vascular smooth muscle cells in human atherosclerotic plaques. Circulation 102: 2680-2686

PENN MS, CUI MZ, WINOKUR AL, BETHEA J, HAMILTON TA, DICORLETO PE, CHISOLM GM (2000) Smooth muscle cell surface tissue factor pathway activation by oxidized low-density lipoprotein requires cellular lipid peroxidation. Blood 96: 3056-3063

PEVERILL RE, TEEDE HJ, SMOLICH JJ, MALAN E, KOTSOPOULOS D, TIPPING PG, MCGRATH BP (2001) Effects of combined oral hormone replacement therapy on tissue factor pathway inhibitor and factor VII. Clin Sci (London) 101: 93-99

PIERCY KT, DONNELL RL, KIRKPATRICK SS, TIMARAN CH, STEVENS SL, FREEMAN MB, GOLDMAN MH (2002) Effects of estrogen, progesterone, and combination exposure on interleukin-1 beta-induced expression of VCAM-1, ICAM-1, PECAM, and E-selectin by human female iliac artery endothelial cells. J Surg Res 105: 215-219

QIAO JH, TRIPATHI J, MISHRA NK, CAI Y, TRIPATHI S, WANG XP, IMES S, FISHBEIN MC, CLINTON SK, LIBBY P, LUSIS AJ, RAJAVASHISTH TB (1997) Role of macrophage colony-stimulating factor in atherosclerosis: studies of osteopetrotic mice. Am J Pathol 150: 1687-1699
ROSENDAAL FR, BRIET E, STIBBE J, VAN HERPEN G, LEUVEN JA, HOFMAN A, VANDENBROUCKE JP (1990) Haemophilia protects against ischaemic heart disease: a study of risk factors. Br J Haematol 75: 525-530

ROSENDAAL FR, HELMERHORST FM, VANDENBROUCKE JP (2002) Female hormones and thrombosis. Arterioscler Thromb Vasc Biol 22: 201-210

SACK MN, RADER DJ, CANNON RO (1994) Oestrogen and inhibition of oxidation in lowdensity lipoproteins in postmenopausal women. Lancet 343: 269-270

SALOBIR BG, KEBER I, VRABIC L (2002) A randomized, placebo-controlled trial of the effects of continuous combined hormone replacement therapy on coagulation and fibrinolytic systems in healthy postmenopausal women. Fertil Steril 78: 1178-1183

SELJEFLOT I, ARNESEN H, HOFSTAD AE, OS I (2000) Reduced expression of endothelial cell markers after long-term transdermal hormone replacement therapy in women with coronary artery disease. Thromb Haemost 83(6): 944-948

SIDELMANN JJ, JESPERSEN J, ANDERSEN LF, SKOUBY SO (2003) Hormone replacement therapy and hypercoagulability. Results from the Prospective Collaborative Danish Climacteric Study. BJOG 110 (6): $541-7$

SKOUBY SO, GRAM J, ANDERSEN LF, SIDELMANN J, PETERSEN KR, JESPERSEN J (2002) Hormone replacement therapy: estrogen and progestin effects on plasma C-reactive protein concentrations. Am J Obstet Gynecol 186: 969-977

SMITH DC, PRENTICE R, THOMPSON DJ, HERRMANN WL (1975) Association of exogenous estrogen and endometrial carcinoma. N Eng1 J Med 293: 1164-1167

SRAMEK A. REIBER JH, GERRITS WB, ROSENDAAL FR (2001) Decreased coagulability has no clinical relevant effect on atherogenesis: observations in individuals with a hereditary bleeding tendency. Circulation 104: 762-767

STEVENSON JC (2000) Cardiovascular effects of oestrogens. J Steroid Biochem Mol Biol 74: 387-393

STORK S, BAUMANN K, VONSCHACKY C, ANGERER $P(2002 a)$ The effect of 17 beta-estradiol on MCP-1 serum levels in postmenopausal women. Cardiovasc Res 53: 642-649

STORK S, VONSCHACKY C, ANGERER P (2002b) The effect of 17 beta-estradiol on endothelial and inflammatory markers in postmenopausal women: a randomized, controlled trial. Atherosclerosis 165: 301-307

SUDHIR K, CHOU TM, CHATTERJEE K, SMITH EP, WILLIAMS TC, KANE JP, MALLOY MJ, KORACH KS, RUBANYI GM (1997a) Premature coronary artery disease associated with a disruptive mutation in the estrogen receptor gene in a man. Circulation 96: 3774-3777

SUDHIR K, CHOU TM, MESSINA LM, HUTCHINSON SJ, KORACH KS, CHATTERJEE K, RUBANYI GM (1997b) Endothelial disfunction in a man with disruptive mutation in oestrogen-receptor gene. Lancet 349: 1146-1147

SULLIVAN TR, KARAS RH, ARONOVITZ M, FALLER GT, ZIAR JP, SMITH JJ, ODONNELL TF, MENDELSOHN ME (1995) Estrogen inhibits the response-to-injury in a mouse carotid artery model. J Clin Invest 96: 2482-2488 
TEDESCHI-REINER E, REINER Z (2001) Estrogens and risks for onset of atherosclerosis. Lijec Vjesn 123: 135-141

TOPPER JN, CAI J, FALB D, GIMBRONE MA (1996) Identification of vascular endothelial genes differentially responsive to fluid mechanical stimuli: cyclooxigenase-2, manganese superoxide dismutase, and endothelial cell nitric oxide synthase are selectively up-regulated by steady laminar shear stress. Proc Natl Acad Sci USA 93: 10417-10422

TOSCHI V, GALLO R, LETTINO M, FALLON JT, GERTZ SD, FERNANDEZ-ORTIZ A, CHESEBRO JH, BADIMON L, NEMERSON Y, FUSTER V, BADIMON JJ (1997) Tissue factor modulates the thrombogenicity of human atherosclerotic plaques. Circulation 95: 594-599

TRIEMSTRA M, ROSENDAAL FR, SMIT C, VANDERPLOEG HM, BRIET E (1995) Mortality in patients with hemophilia. Changes in a Dutch population from 1986 to 1992 and 1973 to 1986 . Ann Intern Med 123: 823-827

VANBAAL WM, EMEIS JJ, KENEMANS P, KESSEL H, PETERS-MULLER ER, SCHALKWIJK CG, VANDERMOOREN MJ, STEHOUWER CD (1999a) Short-term hormone replacement therapy: reduced plasma levels of soluble adhesion molecules. Eur $\mathbf{J}$ Clin Invest 29: 913-921

VANBAAL WM, KENEMANS P, EMEIS JJ, SCHALKWIJK CG, MIJATOVIC V, VANDERMOOREN MJ, VISCHER UM, STEHOUWER CD (1999b) Long-term effects of combined hormone replacement therapy on markers of endothelial function and inflammatory activity in healthy postmenopausal women. Fertil Steril 71: 663670

VANBAAL WM, KENEMANS P, VANDERMOOREN MJ, KESSEL H, EMEIS JJ, STEHOUWER CD (1999c) Increased C-reactive protein levels during short-term hormone replacement therapy in healthy postmenopausal women. Thromb Haemost 81: 925928

VANDENBROUCKE JP, ROSING J, BLOEMENKAMP KW, MIDDELDORP S, HELMERHORST FM, BOUMA BN, ROSENDAAL FR (2001) Oral contraceptives and the risk of venous thrombosis. N Engl J Med 344: 1527-1535

VAHKAVAARA S, SILVEIRA A, HAKALA-ALAPIETILA T, VIRKAMAKI A, HOVATTA O, HAMSTEN A, TASKINEN MR, YKI-JARVINEN H (2001) Effects of oral and transdermal estrogen replacement therapy on markers of coagulation, fibrinolysis, inflammation and serum lipids and lipoproteins in postmenopausal women.Thromb Haemost 85: 619-625

WASSERTHEIL-SMOLLER S, HENDRIX SL, LIMACHER M, HEISS G, KOOPERBERG C, BAIRD A, KOTCHEN T, CURB JD, BLACK H, ROSSOUW JE, ARAGAKI A, SAFFORD M, STEIN E, LAOWATTANA S, MYSIW WJ (2003) Effect of estrogen plus progestin on stroke in postmenopausal women: the Women's Health Initiative: a randomized trial. JAMA 289: 2673-2684
WHITE RE, DARKOW DJ, LANG JL (1995) Estrogen relaxes coronary arteries by opening BKCa channels through a cGMP-dependent mechanism. Circ Res 77: 936-942

WHITE RE, SHELTON J, CHEN SJ, DARLEY-USMAR V, ALLEN L, NABORS C, SANDERS PW, CHEN YF, OPARIL S (1997) Estrogen restores endothelial cell function in an experimental model of vascular injury, Circulation 96: 1624-1630

WILCOX JN, SMITH KM, SCHWARTZ SM, GORDON D (1989) Localization of tissue factor in the normal vessel wall and in the atherosclerotic plaque. Proc Natl Acad Sci USA 86: 2839-2843

WINTERGERST ES, JELK J, RAHNER C, ASMIS R (2000) Apoptosis induced by oxidized low-density lipoprotein in human monocyte-derived macrophages involves CD36 and activation of caspase-3. Eur J Biochem 267: 6050-6059

WORLD HEALTH ORGANIZATION (1995) Oral contraceptive pills and the risk of venous thromboembolism. Prog Hum Reprod Res 39: 2-3

WORLD HEALTH ORGANIZATION (1997) WHO scientific group meeting on cardiovascular disease and steroid hormone contraceptives. Wkly Epidemiol Rec 72: 361-363

YOKOYA K, TAKATSU H, SUZUKI T, HOSOKAWA H, OJIO S, MATSUBARA T, TANAKA T, WATANABE S, MORITA N, NISHIGAKI K, TAKEMURA G, NODA T, MINATOGUCHI S, FUJIWARA H (1999) Process of progression of coronary artery lesions from mild or moderate stenosis to moderate or severe stenosis: A study based on four serial coronary arteriograms per year. Circulation 100: 903-909

ZANGER D, YANG BK, ARDANS J, WACLAWIW MA, CSAKO G, WAHL LM, CANNON RO (2000) Divergent effects of hormone therapy on serum markers of inflammation in postmenopausal women with coronary artery disease on appropriate medical management. J Am Coll Cardiol 36: 1797-1802

ZHAI P, EURELL TE, COOKE PS, LUBAHN DB, GROSS DR (2000) Myocardial ischemia-reperfusion injury in estrogen receptor- $\alpha$ knockout and wild-type mice. Am J Physiol 278: H1640-H1647

ZHU X, BONET B, GILLENWATER H, KNOPP R (1999) Opposing effects of estrogen and progestins on LDL oxidation and vascular wall cytotoxicity: implications for atherogenesis. Proc Soc Exp Biol Med 222: 214221

ZHU Y, BIAN Z, LU P, KARAS RH, BAO L, COX D, HODGIN J, SHAUL PW, THOREN P, SMITHIES O, GUSTAFSSON JA, MENDELSSOHN ME (2002) Abnormal vascular function and hypertension in mice deficient in estrogen receptor B. Sci 295: 505-508 